\title{
Polyunsaturated Fatty Acids Mediated Regulation of Membrane Biochemistry and Tumor Cell Membrane Integrity
}

\author{
Souvik Mukerjee ${ }^{1}$, Abdulaziz S. Saeedan ${ }^{2}$, Mohd. Nazam Ansari ${ }^{2, *}$ and Manjari Singh ${ }^{3, *(\mathbb{C}}$ \\ 1 Department of Pharmaceutical Sciences, Guru Ghasidas Vishwavidyalaya (A Central University), \\ Bilaspur 495009, Chhattisgarh, India; mukherjees388@gmail.com \\ 2 Department of Pharmacology \& Toxicology, College of Pharmacy, Prince Sattam Bin Abdulaziz University, \\ Al-Kharj 11942, Saudi Arabia; a.binsaeedan@psau.edu.sa \\ 3 Department of Pharmaceutical Sciences, Assam University, Silchar 788011, Assam, India \\ * Correspondence: nazam.ansari@gmail.com (M.N.A.); manjari.pharm@gmail.com (M.S.); \\ Tel.: +96-6535870553 (M.N.A.); +91-7599211639 (M.S.)
}

Citation: Mukerjee, S.; Saeedan, A.S.; Ansari, M..N.; Singh, M. Polyunsaturated Fatty Acids Mediated Regulation of Membrane Biochemistry and Tumor Cell Membrane Integrity. Membranes 2021, 11, 479. https://doi.org/10.3390/ membranes11070479

Academic Editors: Tanima Bose and Terry Hébert

Received: 14 May 2021

Accepted: 24 June 2021

Published: 28 June 2021

Publisher's Note: MDPI stays neutral with regard to jurisdictional claims in published maps and institutional affiliations.

Copyright: (c) 2021 by the authors. Licensee MDPI, Basel, Switzerland. This article is an open access article distributed under the terms and conditions of the Creative Commons Attribution (CC BY) license (https:// creativecommons.org/licenses/by/ $4.0 /)$.

\begin{abstract}
Particular dramatic macromolecule proteins are responsible for various cellular events in our body system. Lipids have recently recognized a lot more attention of scientists for understanding the relationship between lipid and cellular function and human health However, a biological membrane is formed with a lipid bilayer, which is called a P-L-P design. Our body system is balanced through various communicative signaling pathways derived from biological membrane proteins and lipids. In the case of any fatal disease such as cancer, the biological membrane compositions are altered. To repair the biological membrane composition and prevent cancer, dietary fatty acids, such as omega-3 polyunsaturated fatty acids, are essential in human health but are not directly synthesized in our body system. In this review, we will discuss the alteration of the biological membrane composition in breast cancer. We will highlight the role of dietary fatty acids in altering cellular composition in the P-L-P bilayer. We will also address the importance of omega-3 polyunsaturated fatty acids to regulate the membrane fluidity of cancer cells.
\end{abstract}

Keywords: biological membrane; breast cancer; polyunsaturated fatty acid; membrane remodeling; P-L-P membrane channel; ALA and GLA

\section{Introduction}

A fatal disease that originated in 460-370 BC is slowly engulfing modern civilization, a disease that scientists have termed cancer. From a chemical point of view, just as matter is formed by the combination of atoms, our body organ system is developed according to this parasitic trend from cells to tissues, from tissues to organs, and from organs to body systems [1]. Each cell protects its existence through division. After a certain period, each cell dies. Normal cell division becomes defective due to a stimulus or an external infection. When the cell divides at a much higher rate than the normal division rate, it is called a tumor [2]. If the cell spreads in the body system and then forms a new tumor, then the division of these cells is uncontrolled, and the cells gain immortality; then, it is termed cancer. More than 100 cancers have been discovered so far. For many years, scientists have been working tirelessly to bring this disease under control [3].

At present, scientists have rediscovered the importance of cell membranes to deliver different chemotherapeutic agents in cancer. This is because the cell membrane is a thin membrane that protects the cell from external injury and protects the cell organ within the cytoplasm. This cell membrane comprises three layers of protein-lipid-protein and $52 \%$ protein, $40 \%$ lipid, and $8 \%$ carbohydrate [4-8]. In cancer, a large amount of fatty acid biosynthesis occurs in the cell membrane, resulting in new membranes in tandem with uncontrolled cell division [9]. In the case of breast cancer, not only are fatty acids and phospholipids converted into a cell membrane, but the membrane's biophysical atmosphere 
is also affected. Breast cancer is on the rise among women all over the world [10]. This disease is the most common after skin cancer. In this type of cancer, the estrogen receptor driven by the estrogen hormone in the cell membrane plays a crucial role. Cell membrane composition and its function are being routinely tested to restore normalcy and prevent cancer [11-13]. The role of omega-3 polyunsaturated fatty acids (PUFAs) in controlling tumor cell membrane fluidity, drug resistance, and altered membrane biophysics are still under question.

On the other hand, it has been found that saturated fatty acids increase the risk of breast cancer [14,15]. Omega-3 PUFAs are not directly synthesized in our body, and they must be taken from outside. All these fatty acids are found in various animal and vegetable sources [16-19]. This review will discuss how the cell membrane changes in estrogen receptor-positive $(\mathrm{ER}+)$ breast cancer. Why have polyunsaturated fatty acids been chosen instead of saturated fatty acids? How do these types of fatty acids prevent breast cancer by altering membrane biophysics?

\section{Biophysical Architecture of Cellular Membrane}

In the nineteenth century, a scientist named Charles E. Overton discovered that the membrane that protects cells from external injuries is lipid in nature. Lipids are one of the cell membrane building blocks covering all the cells in a cell's cytoplasm [20]. Finally, in 1972, after conducting various experiments, two scientists, Sanger and Nicolson, described the cell membrane as looking a lot like a fluid mosaic. Thereafter, the cell membrane was named as fluid mosaic model. The cell membrane is composed of a lipid distillation in which some proteins are immersed [21]. This fluid mosaic model that renovated by Sanger and Nicolson is universally accepted till date [22]. Communication between one cell and another is carried out through many receptors and signal transduction pathways [23]. It also helps in the activities of different types of enzymes, including fusion, fission, endocytosis, and the exchange of various substances [24].

This lipid bilayer is responsible for the normal formation of each cell membrane. It can be easily seen using an electron microscope. The animal cell membrane is made up of lipid molecules and is around $50 \%$ of its mass [25]. The $1 \times 1 \mu \mathrm{m}$ space of the two-layer lipid contains approximately $5 \times 10^{6}$ lipid molecules. Again, the cell membranes of small animals contain (approximately) $10^{9}$ lipid molecules. There are various types of membranes present in eukaryotic cells, such as plasma, endosomal, nuclear, and mitochondrial membranes, where lipid composition is specified in each membrane. Lipid composition is mainly cholesterol/phospholipid and is also influenced by lipid raft formation [26]. In animals and bacteria, the tails of cell membranes are usually made up of fatty acids, they can differ in length of carbon chains (usually exists between 14 and 24 carbon atoms). A tail usually has one or more cis doubles, i.e., unsaturated, and another tail is saturated. A small kink in the tail is created by each double bond. This creates a difference in the length and fullness of the fatty acid [27]. This difference affects how the phospholipid molecules entangle each other and affect the fluidity of the cell membrane. Phosphoglycerides are the main component of biological membranes that have a three-carbon glycerol backbone and two long-chain fatty acids attached to the adjacent carbon atom of the glycerol molecule through an esteric bond. The two fatty acid chains attached to the molecule of glycerol are non polar hence hydrophobic while the polar heads which mainly consists of the phosphate group attached to the third carbon of the glycerol molecule is hydrophilic. Many fatty acids and head groups combine to form different phosphoglycerides in the cell membrane [28-31].

Another essential phospholipid is sphingomyelin, which is made from sphingosine. Sphingosine is a long acyl chain, having one amino group and two hydroxyl groups. In this sphingomyelin, the fatty acid tail is attached to the amino group, and the phosphocholine group is attached to the terminal hydroxyl group. This free hydroxyl group polarizes the edges of this phospholipid because it can quickly form a hydrogen bond. In this way, phosphatidylcholine, phosphatidylserine, phosphatidylethanolamine, and sphingomyelin interact with the lipid water molecules and create more than half of the mass [32]. In 
addition to all these phospholipids, there are also two layers of cell membranes in the lipid layer, namely cholesterol, which is present in a large amount, and glycolipids. There is cholesterol for each phospholipid molecule. Cholesterol is a type of sterol made up of a single polar hydroxyl group and a non-polar hydrocarbon chain (Figure 1). Now, we will discuss how differential lipid is synthesized and controlled in the cell membrane [33-35].

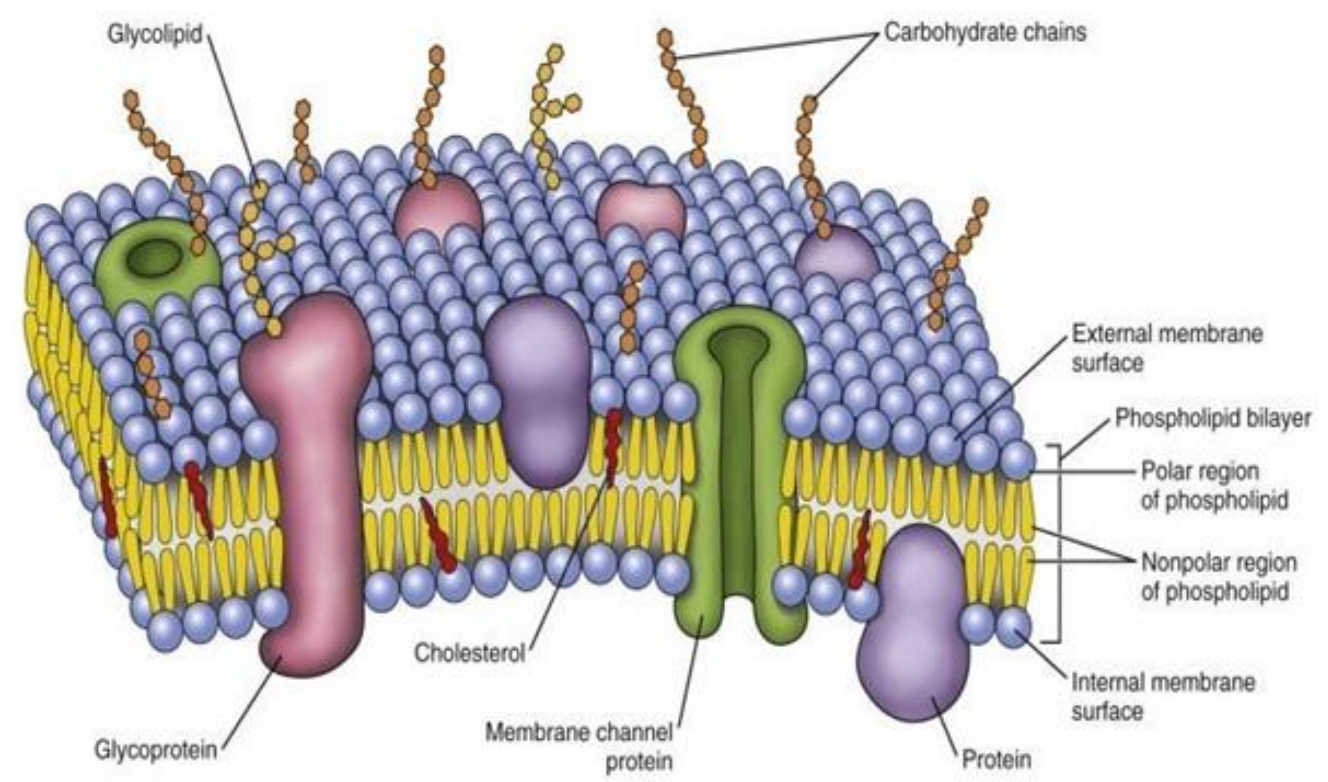

Figure 1. Components and layers of biological membrane.

\section{Biosynthesis of Fatty Acids in the Cell Membrane}

Lipid metabolism in eukaryotic cells is accomplished by forming various chemical compounds centered on many metabolic reactions. The lipid is mainly divided into six parts, including the following: (1) Fatty acid mainly acts as a stimulant of lipid biosynthesis and produces metabolites containing oxygen. (2) Free sterols act as a cell membrane shape provider. (3) Sterol esters are mainly made from fatty acids and sterols. (4) Triacylglycerol is made from glycerol and fatty acid. (5) Phospholipids are mainly made from fatty acids, glycerol, and alcohol. For example, inositol, serine, choline, and ethanolamine act as a cell membrane shape provider [36]. One of the major phospholipids in the biological membrane is phosphoglyceride, which is an important substrate for various lipid kinases and phosphatases. As a result, it can form various biologically active compounds, which are called phosphoinositides. They are acidic phospholipids present in the cell membrane and interact with each membrane compartment protein and are phosphorylated with the help of phosphoinositide kinases [37]. (6) Sphingolipids are long fatty acids and are responsible for cell surface formation. As a result, endocytosis, cell cycle control, etc., are efficiently completed. The so-called lipid class discussed above is made up of acetyl COA in the cell's cytoplasm. Lipid biosynthesis mainly requires two-branched acetyl COA, one part of which produces sterol and the other part fatty acids, which paves the way for triacylglycerol biosynthesis [38-43]. In eukaryotic cells, there are several types of membranes present, such as plasma, endosomal, nuclear, and mitochondrial membranes. Specific lipids are present in certain levels within a particular membrane and help the cell membrane move in a particular way [44]. An essential component of this eukaryotic cell is cholesterol, which regulates the cell membrane's speed and function (Figure 2). It is the last component of the sterol biosynthetic pathway, and this component forms a semipermeable barrier that regulates membrane fluidity [45]. 


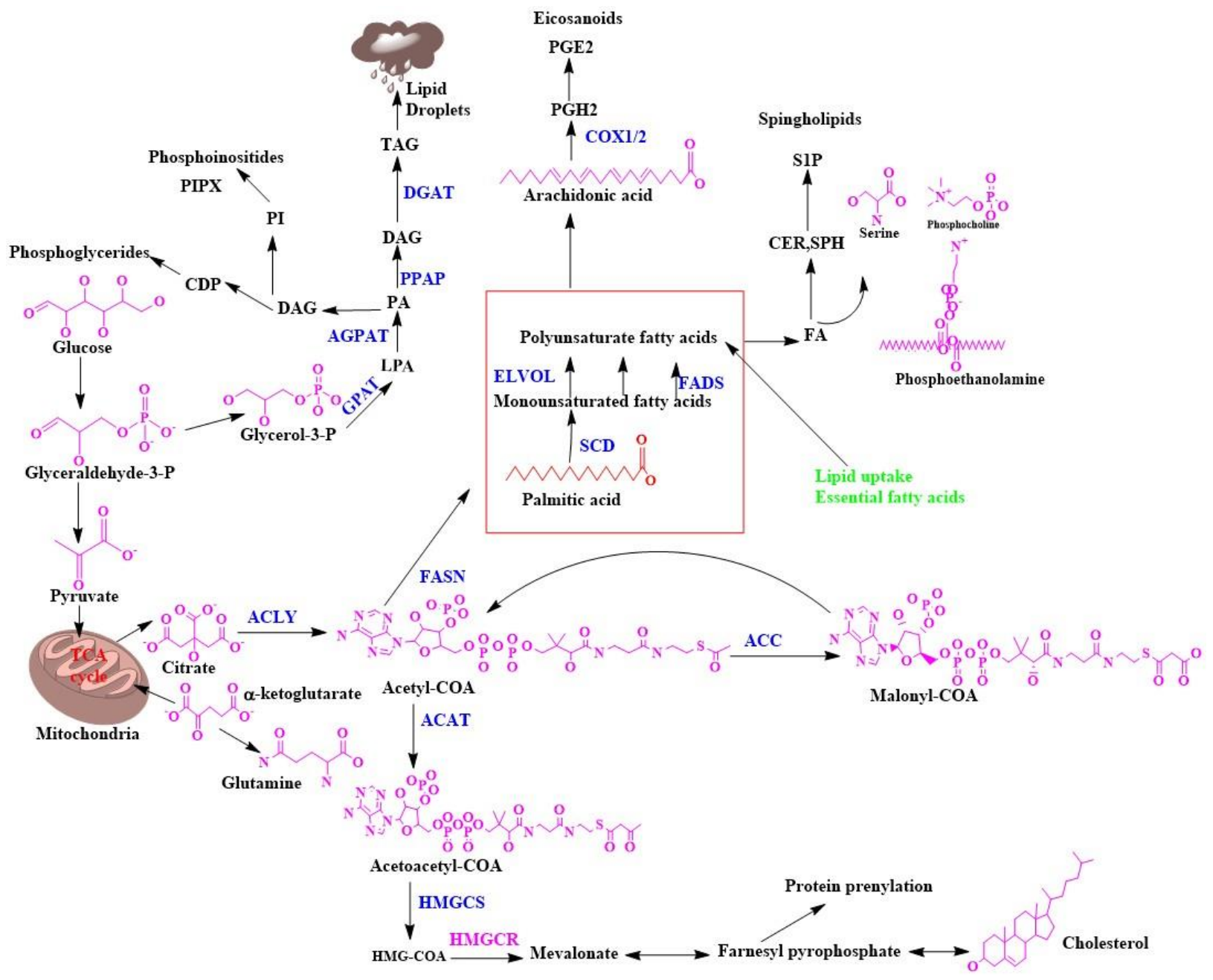

Figure 2. Biosynthesis of lipids in biological membranes.

\section{Membrane Biophysical Difference between a Normal Cell and Cancer Cell}

We know that when a tumor cell turns into a malignant cell, that cell spreads to every part of the body very quickly with the birth of new malignant cells, resulting in the formation of a new cell membrane in each cell. Important components vary in the path of lipid biosynthesis (Figure 3) [46]. This lipid synthesis gradually decreases and increases in the cancer cell and creates new cell membranes, depending on the nature, stage, etc., of different cancer cells, and depending on the other lipids in the cell membrane. We discussed in the last portion that lipid molecules are formed by the connection of the polar head and hydrophobic tail. A thermodynamic force is mainly responsible for the shape of the lipid molecule. This force helps the cell membrane to form micelles or bi-layered sheets [47]. Due to the presence of lipid polar head groups, differences in shape, charge, character, etc., are seen in the membrane, such that the long polar group phosphatidylcholine, due to the amphiphilicity of sphingomyelin, looks much like a cylindrical shape. Sphingolipids have long fatty acid chains and are converted from solid to gel by sterol. Asymmetry of lipid can be seen inside and outside the cell membrane of a normal cell. Phosphatidylcholine and sphingomyelins are zwitterionic lipids located outside of the cell membrane. 

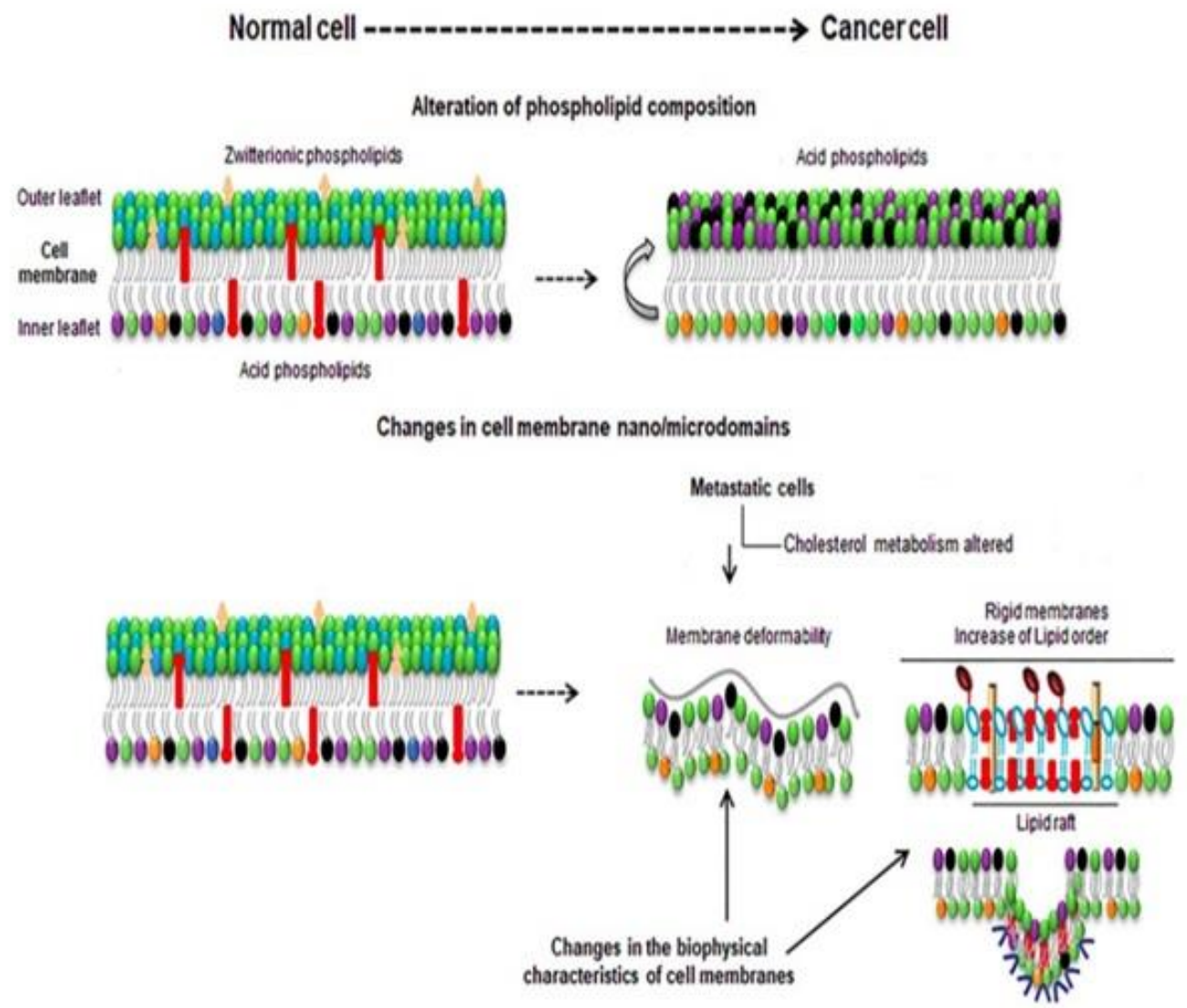

Figure 3. Composition and biophysical changes of a normal cell and cancer cell.

On the other hand, phosphatidylethanolamine is a phospholipid that is comprised of glycerol esterified with two fatty acids and phosphoric acid where the phosphate group is attached with choline and forms phosphatidylcholine. Phosphatidylcholine is combined with ethanolamine and forms phosphatidylethanolamine. They are located in the inner leaflet of the cell membrane. The presence of phosphoethanolamine in the inner leaflet creates a negative charge on the cell membrane surface. It facilitates the passage of various hydrolysis processes such as phospholipase $C$ to inositol 1,4,5-triphosphates, and diacylglycerol that act as secondary messengers [48].These substances are again called a kind of secondary messenger. When a normal cell turns into a cancer cell, all the changes mentioned above can be noticed; for example, a negative charge is created outside of the cell membrane in the cancer cell, as a result of which the environment outside the cell membrane becomes acidic and the fluidity of the membrane changes [49]. The different shapes of the lipids in the cell membrane, depending on the temperature, change from lipid gel to solid, increasing their hydrophobic parts, but there is no change in the hydrocarbon tail. The fluidity of a cell membrane depends on the cholesterol in it. When the cell membrane changes to a liquid state, it contains $8-15 \%$ cholesterol. Depending on the nature of cancer, cholesterol metabolism repeatedly changes in the cell membrane [48]. In metastatic cells, cholesterol levels are lower than in normal cells. In the case of multidrug-resistant cells, cholesterol levels are high; thus, the membrane becomes more rigid and less permeable for drugs, developing drug resistance. In addition to cholesterol, any other above-discussed molecules are higher in multidrug-resistant cells than normal cells. Increasing cholesterol levels increases the malignant transformations, hyper-growth, and invasiveness. Lipid rafts also interact with other proteins such as integrins, CD44, and CD24. These receptors are involved in tumor progression [50-52]. 


\section{Pivotal Role of Membrane Lipid and Cholesterol for Reprogramming of Breast Cancer}

Breast malignant growth cells often show explicit changes in their metabolic movements. The most popular metabolic irregularity connected to disease cell science is the Warburg impact, which expands glycolytic transition, diminishes TCA cycle motion, and expands glutamine usage for anabolic pathways [53-56]. Metabolic reconstructing through a change in lipid biosynthesis and cholesterol blend is additionally a sign of breast cancer but is poorly understood. This metabolic reconstructing upholds the expanded creation of metabolic intermediates for the union of proteins, nucleic acids, and lipids. All these are essential for the fast multiplication of breast cancer cells. It has been demonstrated that mutations in major oncogenes, that PI3K/AKT, KRAS, and MYC, mediate metabolic shifts in cancer cells and activate de novo fatty acid(FA) synthesis $[57,58]$. Profoundly proliferative breast malignancy cells fulfill the need for lipid/cholesterol by either expanding the taking up of exogenous lipids and lipoproteins or persistently reprogramming their endogenous biosynthetic pathways. FA biosynthesis is a contributory element of early phase malignancy advancement, disease cell development, and endurance. Unnecessary lipids and cholesterol in disease cells are stored in lipid drops. This is critical because raised lipid beads and stored cholesteryl ester content in tumors are viewed as signs of disease forcefulness [59-63]. These lipids arise from acetyl Co A and contain FA. The FA building blocks are obtained from either exogenous sources or amalgamation of FA. In this manner, it is essential to see how lipid/cholesterol biosynthesis is upgraded in malignant growth, because most normal human cells favor exogenous sources. However, tumors blend FA again and regularly show a shift toward FA combination [64]. From a robotic viewpoint, it is intriguing to take note that, by and large, the endogenous combination of lipids transfers physiological/pathophysiological prompts that synthetically indistinguishable exogenous lipids cannot mirror. Oncogene-changed disease cell requirements increase the amount of cholesterol to help their rapid development [65].

Notwithstanding upgraded cholesterol amalgamation again, the interaction of cholesterol take-up is likewise firmly directed by the flagging movement of the epidermal development factor receptor (EGFR), which is expanded in malignant growth. Now, we discuss how omega-3 PUFAs mediate regulation of membrane channel and tumor cell membrane fluidity [66].

\section{Introductory Concept of Omega-3 PUFAs}

Omega-3 PUFAs gather fundamental polyunsaturated unsaturated fats that assume significant roles in biological cell construction and cell flagging. Assignment 3 or 6 underlies this mechanism, alluding to the two-fold bond on the third or sixth carbon separately from the methyl branch. The most plentiful dietary polyunsaturated fatty acids are the shortchain omega-3 alpha-linolenic acids (ALAs), which are obtained from plant oils $[67,68]$. The longer chain omega-3 PUFAs, eicosapentanoic acid (EPA), and docosahexaenoic acid (DHA), usually referred to as marine unsaturated fats, are most proficiently obtained from fatty cold water fish such as salmon. They should be obtained from ALA and linolenic acid (LA) separately [69]. The desaturases and elongases have a more special proclivity for ALA than LA due to the overall 10-fold higher admission of LA, and, for the most part, more AA than EPA and DHA is formed. Whether ingested or synthesized, PUFAs are either oxidized for fuel, stored in triacylglycerol, taken up in phospholipid films for inevitable use as substrates by cyclooxygenase (COX) and lipoxygenase (LOX) compounds, or utilized as ligands for G receptors [70-72]. Either LA or ALA is changed into bioactive lipids due to low uptake into phospholipid films. In any case, 5 to $10 \%$ of both LA and ALA can be changed into the longer chain PUFAs, which are promptly taken up in phospholipid layers and structure the substrates for transformation to bioactive lipid items COX and LOX proteins [73]. The omega-3 unsaturated fats EPA and DHA and their subordinates are significant for retinal and mental health, intellectual capacity, and the creation of 
negligibly reactive eicosanoids, proresolving mediators named resolvins, and different tissue protectins [74].

However, most of the bioactive lipid mediators of interest are a consequence of COX and LOX compound movement in the long-chain PUFAs. EPA, DHA, AA, and 15-LOX follow up on the short-chain LA to shape 13(S)-hydroxyoctadecadienoic. Cancer is likely known to increase mammary tumor expansion. EPA and DHA contend with AA as substrates for COX and LOX proteins, even though EPA is a less suitable substrate than AA, especially for COX. Upon inflammatory stimulus, the catalyst phospholipase A2 discharges AA from phospholipid layers of monocytes, and overwhelmingly proinflammatory subsidiaries are created. COX-1 and COX-2 chemicals are liable for AA-inferred prostaglandin E2 and another arrangement of two prostaglandins and thromboxanes. 5LOX, 12-LOX, and 15-LOX are responsible for the arrangement of four leukotrienes and lipoxins (Figure 4) [75,76].

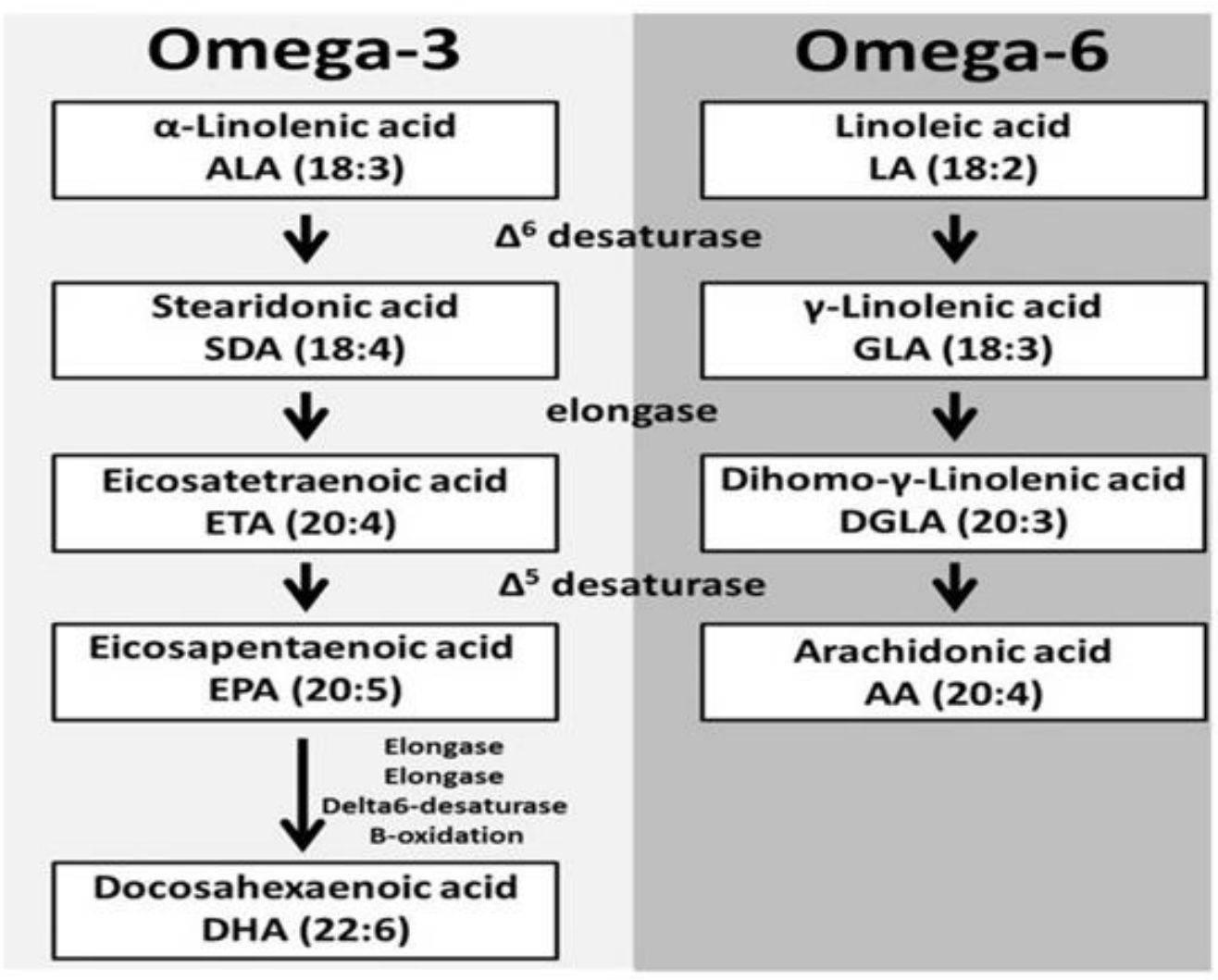

Figure 4. Polyunsaturated fatty acid biosynthesis.

\section{Intermediate Cross-Talk of ALA and Gamma-Linolenic Acid (GLA)}

The more significant part of the work evaluating how ALA and GLA may diminish breast malignancy hazard has been studied through in vitro or transgenic mouse models. A decrease in oncogenic protein is monitored through disturbance of plasma film lipid rafts, a decrease in cytokine production, and an expansion in apoptosis following the enactment of the plasma layer GRP120 protein [77-80]. ALA and GLA disturb lipid rafts, sphingolipid/cholesterol-improved miniature spaces of plasma layers that streamline motioning by concentrating proteins. Lipid rafts are especially significant for a few tyrosine kinase receptors. Decreases in epidermal development factor receptor and human epidermal development factor-2 receptor level and enactment have been exhibited in changed and harmful cells. A lessening in epidermal development factor receptor and human epidermal development factor-2 flagging would be relied upon to diminish multiplication [81]. A reduction in Ki-67 has been observed in favorable and dangerous mammary tissue after ALA and GLA supplementation in most preclinical models. Other preclinical studies 
highlight that ALA and GLA increase expression of BRCA1/2, phosphatase, and tensin homolog (PTEN) and different proteins related to the cell cycle and DNA repair [82-84].

\section{Mechanism of GLA for Breast Cancer Prevention}

The upstream omega-6 GLA may possess anti-cancer effects especially breast cancer. and it is a guaranteed dietary hotspot for disease counteraction and treatment. Nonetheless, the upstream omega- 6 can be viably changed into arachidonic acid (AA) by a progression of unsaturated fat digestion chemicals. Upon uptake, LA (the antecedent of omega-6) will be changed into GLA within sight of $\Delta-6$ desaturase (D6D), trailed by a two-carbon bond stretching by elongase to become DGLA, and lastly will be de-immersed by $\Delta-5$ desaturase (D5D) to shape AA. COX is a major lipid peroxidizing enzyme, omega-6s can undergo a free radical pathway during lipid peroxidation and produce different PUFA-inferred metabolites $[85,86]$. For example, GLA and AA, both significant substrates for COX, can create single-arrangement prostaglandins (PGs-1) and double-arrangement prostaglandins (PGs-2) separately during COX-catalyzed lipid peroxidation. DGLA and AA can utilize various free radical pathways during lipid peroxidation and produce unmistakable free radical metabolites [87]. GLA may apply the opposite disease impact by creating prostaglandin E1 (PGE1) and the restrictive free radical metabolites from its COX-catalyzed lipid.

However, all the omega- 6 can be directly consumed in the everyday diet. LA, the forerunner of omega-6, is more bountiful in plant seeds and oils and consequently is viewed as the fundamental dietary wellspring of all omega-6. Studies show that LA can be involved in both pro and hostile to malignant activities. For instance, LA invigorates cell expansion in the human bosom. LA can be desaturated and changed into GLA, which is catalyzed by the D6D protein. GLA has appeared to apply the opposite disease expansion impacts by affecting quality and protein articulation, disturbing cell cycle movement and inciting apoptosis. GLA from basic primary segments of the cell, atomic, and organelle layers directly affects ordinary cell capacity and digestion [88]. GLA is joined to the phospholipid film layer and is induces cell film cooperation-for example, cell-cell grip and receptor flagging framework. GLA sets off cytochrome c delivery related to changes in mitochondrial digestion and expanded caspase 3 movement, accordingly prompting cell apoptosis [89]. GLA modifies mitochondrial digestion and construction by affecting mitochondrial film arrangement and diminishing hexokinase and carnitine palmitoyltransferase I activity, accordingly, and promoting apoptosis. The primary impacts of GLA in ER+ breast malignancy intercede through the ER pathway [90].

\section{Role of Omega-3 PUFAs in the Regulation of Membrane Channel Activity}

Various experiments have shown that omega-3 PUFAs exhibit anti-invasive and antimetastatic properties by interfering with various functions of ion channels present in the biological membrane. However, we discuss the role of ion channels in the biological membrane for the spread of cancer and we also discuss how omega-3 PUFAs help in cancer prevention by targeting the ion channel [91]. The presence of approximately 300 types of ion channels can be observed in the cell membrane-for example, voltage-gated, ligandgated, and lipid-gated ion channels, etc. However, various studies have shown that the voltage-gated sodium $\left(\mathrm{Na}_{\mathrm{v}}\right)$ channel plays an important role in cancer in all these ion channels [92]. The ions enter the cell membrane through the transmembrane of the semipermeable cell membrane. This $\mathrm{Na}_{\mathrm{v}}$ channel is a transmembrane protein that is activated by the electrical charge created in the cell membrane and helps the sodium ion to travel through the membrane. Electrical potential in the membrane helps to open and close this channel [93]. This channel is formed by the insertion of a single polypeptide chain and four homologous domains through alpha and beta subunits covered by protein. Each subunit works differently in the membrane. When the protein of the alpha subunit is secreted, it enters the channel through sodium voltage, while the protein of the beta subunit remains in the visible state. The alpha subunit has four domains with six membrane- 
spanning segments in each: s1 to s6. This alpha subunit ion uses pores and forms one or two subunits [94]. The protein of this alpha subunit is mainly divided into nine parts that are represented by the $\mathrm{Na}_{\mathrm{v}}$ signal, e.g., $\mathrm{Na}_{\mathrm{v}} 1.1$ to $\mathrm{Na}_{\mathrm{v}} 1.9$. The protein of each alpha subunit is differentiated by gene sequence, such as SCN1A for Nav 1.1, SCN2A for Nav1.2, SCN3A for Nav1.3, SCN4A for Nav1.4, SCN5A for Nav1.5, SCN8A for Nav1.6, SCN9A for Nav1.7, SCN10A for Nav1.8, SCN11A for Nav1.9. Again, the beta subunit is represented by the $\mathrm{Na}_{\mathrm{v}} \beta$ signal where it is distinguished by the SCN2B gene for $\mathrm{Na}_{\mathrm{v}} \beta 2, \mathrm{SCN} 3 \mathrm{~B}$ for $\mathrm{Na}_{\mathrm{v}} 3 \beta$, and SCN4B for $\mathrm{Na}_{\mathrm{v}} \beta 4$ [95]. At present, various experiments have shown that $\mathrm{Nav} \alpha$ and $\mathrm{Na}_{\mathrm{v}} \beta$ subunits are present in the case of non-excitable cancer tissue, such as breast, colon, lung, prostate, and colon cancers. On the other hand, in the case of non-cognate cancerous tissue, the alpha and beta subunits are not deeply evident [96]. In Table 1, the role of each subunit in cancer is described. Now, we will discuss how omega-3 PUFAs prevent cancer by targeting this voltage-gated sodium channel. Omega-3 PUFAs modulate the ion channel by exhibiting anti-invasive and antimetastatic properties. Preliminary tests have shown that omega-3 PUFAs combine directly with the Nav1.5 channel protein to control cancer by reducing its deepest latent state [97]. Later, in the case of human breast cancer cells, the application of DHA at a concentration of $0.5-10 \mu \mathrm{m}$ has been shown to reduce the expression of the SCN5A gene by binding to the DHA lipid-sensitive nuclear receptor, thereby reducing the latent state of $\mathrm{Na}_{\mathrm{v}} 1.5$. The downstream protagonist NHE-1 helps in cancer prevention by reducing activation and hydrogen ion efflux by reducing extracellular matrix proteolytic activity, which is shown in Figure 5 [98].

Table 1. Role of various sodium channel subunits in different types of cancer.

\begin{tabular}{|c|c|c|c|}
\hline Name of Sodium Channel & Type of Cancers & Expression & Mechanism \\
\hline Nav1.5 & Breast & $\begin{array}{l}\text { Up-regulated mRNA, } \\
\text { and protein }\end{array}$ & $\begin{array}{l}\text { Increase invasion by increasing Src activity } \\
\text { and allosteric activation of NHE-1 }\end{array}$ \\
\hline Nav1.5 & Colorectal & $\begin{array}{l}\text { Up-regulated mRNA, } \\
\text { and protein }\end{array}$ & $\begin{array}{l}\text { Increase invasion by the regulation of } \\
\text { transcriptional pathway Pka/Erk }\end{array}$ \\
\hline Nav1.5 & Ovarian & $\begin{array}{l}\text { Up-regulated mRNA, } \\
\text { and protein }\end{array}$ & $\begin{array}{l}\text { Increase migration, invasion, and } \\
\text { proliferation by increasing the } \\
\text { window currently }\end{array}$ \\
\hline Nav1.6 & Cervix & $\begin{array}{l}\text { Up-regulated mRNA, } \\
\text { and protein }\end{array}$ & $\begin{array}{l}\text { Increased invasion and boosted activity of } \\
\text { MMP2 and NHE-1 }\end{array}$ \\
\hline Nav1.7 & Prostate & $\begin{array}{l}\text { Up-regulated mRNA, } \\
\text { and protein }\end{array}$ & Cell motility increased via galvanotaxis \\
\hline Nav1.7 & Lung & $\begin{array}{l}\text { Up-regulated mRNA, } \\
\text { and protein }\end{array}$ & $\begin{array}{l}\text { Increased invasion and dysregulation of } \\
\text { sodium homeostasis, an increase in sodium } \\
\text { ion, and depolarization of cell membrane }\end{array}$ \\
\hline $\operatorname{Nav} \beta 1$ & Breast & $\begin{array}{l}\text { Down-regulated mRNA, } \\
\text { protein }\end{array}$ & $\begin{array}{l}\text { Increased invasion by decreasing cell } \\
\text { adhesion and facilitating cell migration }\end{array}$ \\
\hline $\operatorname{Nav} \beta 1$ & Lung & $\begin{array}{l}\text { Down-regulated mRNA, } \\
\text { protein }\end{array}$ & $\begin{array}{l}\text { Increased invasion by decreasing cell } \\
\text { adhesion and facilitating cell migration }\end{array}$ \\
\hline $\operatorname{Nav} \beta 2$ & Prostate & $\begin{array}{l}\text { Up-regulated mRNA, } \\
\text { and protein }\end{array}$ & $\begin{array}{l}\text { Increased invasion by promotion of bipolar } \\
\text { cell morphology enhanced cell adhesion }\end{array}$ \\
\hline $\operatorname{Nav} \beta 3$ & Bone & $\begin{array}{l}\text { Up-regulated mRNA, } \\
\text { and protein }\end{array}$ & $\begin{array}{l}\text { Increased apoptosis by increasing the p } 53 \\
\text { dependent apoptotic pathway }\end{array}$ \\
\hline Nav $\beta 4$ & Breast & $\begin{array}{l}\text { Down-regulated } \\
\text { mRNA, protein }\end{array}$ & $\begin{array}{l}\text { Increased invasion by enhancing } \\
\text { RhoA activity }\end{array}$ \\
\hline
\end{tabular}




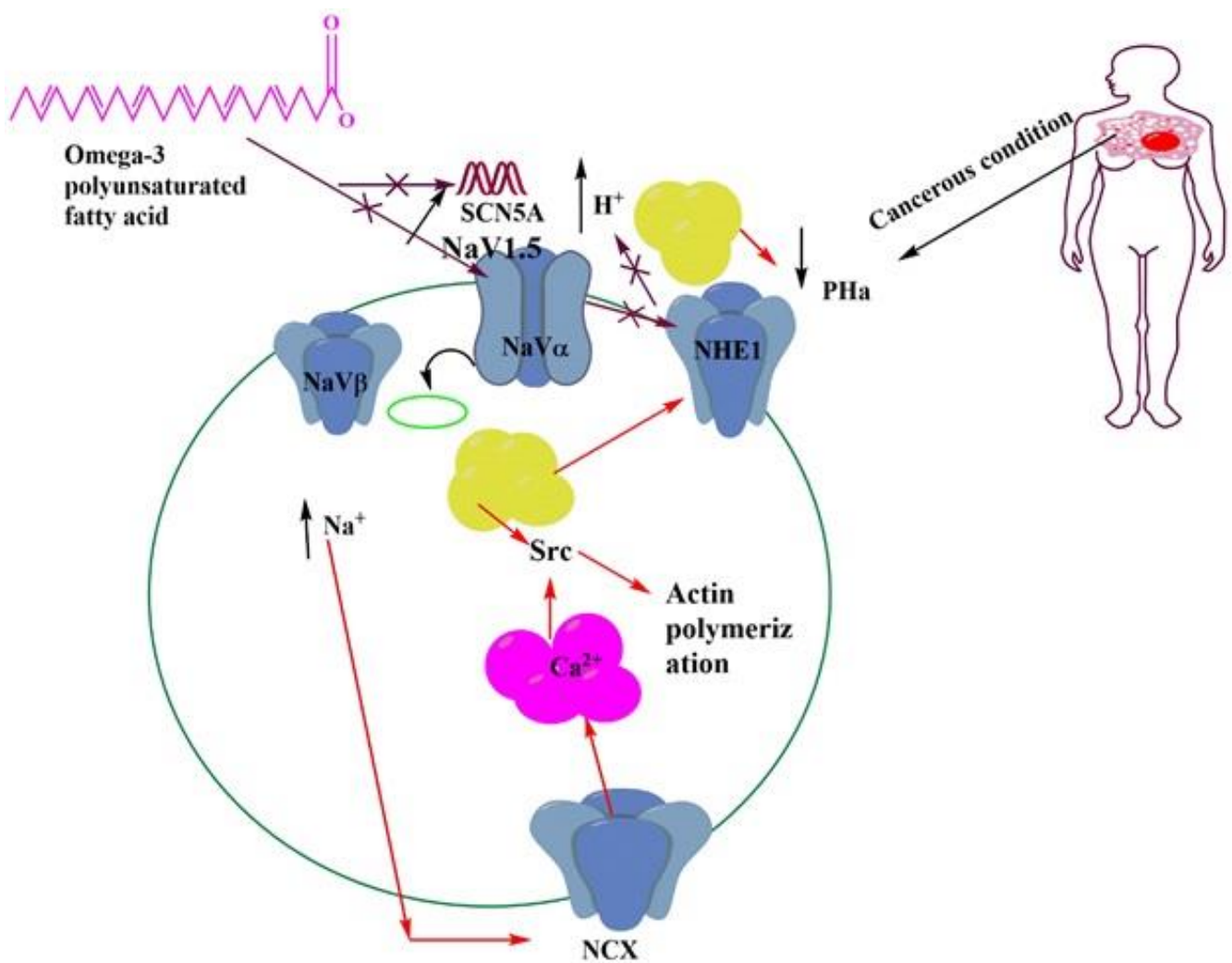

Figure 5. Omega-3 PUFAs in the regulation of channel activity and prevention of cancer progression.

\section{Translational Impact of PUFAs}

Omega-3 PUFAs are easily assimilated into the lipid layer of the cell membrane, especially for tumor cells, because these types of fatty acids are amphiphilic. Various experiments have shown that omega-3 PUFAs, in addition to FDA-approved anticancer drugs, also increase the desired efficacy of anticancer drugs and modulate biological membranes [99-102]. DHA combination sensitized colon cancer cells tonon steroidal anti-inflammatory drug (sulindac sulfide) induced apoptosis, leading to enhanced growth suppression of human colon cancer xenografts. PUFAs have also enhanced the susceptibility of human colorectal cancer cells combined with 5-fluorouracil for mammary carcinoma in addition with celecoxib, tamoxifen in breast cancer, cisplatin in lung cancer, gemcitabine in breast and liver cancers, doxorubicin, vincristine, and fludarabine in leukemia. A total of 550 clinical trials under the investigation of the government suggested that the effect of PUFAs is highly impactful on various chronic diseases in humans [103]. Various investigation results indicated that EPA at $2 \mathrm{~g} / \mathrm{d}$ for 3 mo also reduces colonic crypt cell proliferation and increases apoptosis in normal colonic mucosa [104]. Alternatively, as part of a parenteral nutrition plan, omega-3 PUFAs can be given as intravenous lipid emulsions. In patients recovering from surgical removal of gastric tumors, omega-3 PUFA emulsion-based parenteral feeding lowers inflammatory response and the rate of inflammatory sequelae [105]. In patients given $3 \mathrm{~g}$ of omega-3 PUFA daily for 7 days before surgery for colorectal cancer, EPA was rapidly absorbed into the colonic mucosa and the colonic muscle layer, supporting assertions about the therapeutic benefits of omega-3 PUFA. More clinical research is needed to determine the effect of EPA and/or DHA dose and duration on critical molecular targets, such as cell plasma [106]. Some of the formulations are described in Table 2. 
Table 2. Contribution of different omega-3 PUFAs for the prevention of different cancer.

\begin{tabular}{cccc}
\hline Name of PUFA & Type of Cancer & Cell Line and Animal Study & Effective Dose \\
\hline Eicosapentaenoic acid & B lymphocyte (lymphoblast) & U 266 & $50 \mu \mathrm{M}$ \\
\hline Docosahexaenoic acid & B lymphocyte (lymphoblast) & U 266 & $100 \mu \mathrm{M}$ \\
\hline Eicosapentaenoic acid & Plasma cell leukemia & L363 & L363 \\
\hline Docosahexaenoic acid & Plasma cell leukemia & PC3 & $100 \mu \mathrm{M}$ \\
\hline Arachidonic acid & Prostate cancer & PC3 & $50 \mu \mathrm{M}$ \\
\hline Eicosapentaenoic acid & Prostate cancer & MDA-MB-231 & $1 \mu \mathrm{M}$ \\
\hline Docosahexaenoic acid & Breast cancer & A459 & $20 \mu \mathrm{M}$ \\
\hline Docosahexaenoic acid & Non-small cell lung cancer & CR HT-29 & $25 \mu \mathrm{M}$ \\
\hline Eicosapentaenoic acid & Colon cancer & $20 \mu \mathrm{mol} / \mathrm{L}$ \\
\hline
\end{tabular}

\section{Conclusions and Future Perspectives}

Nowadays, advancement in lipid research plays a vital role in understanding the importance of plasma membrane composition and its structure in chronic diseases such as cancer. Here, we have summarized the role of omega-3 PUFAs in membrane channel integrity and breast cancer prevention. Since membrane lipid composition influences cellular function, future research should consider the role of omega-3 PUFAs in the modulation of membrane integrity and controlling different membrane pumps to alter drug availability. In the future, research based on lipids will provide new techniques and approaches to answer various questions that remain unanswered about the benefits of omega-3 PUFAs.

Author Contributions: Writing and original draft preparation, S.M.; proofreading, manuscript preparation, and correction, A.S.S. and M.N.A.; conceptualization, review, editing, supervision, and resources, M.S. All authors have read and agreed to the published version of the manuscript.

Funding: This research received no external funding.

Institutional Review Board Statement: Not applicable.

Informed Consent Statement: Not applicable.

Data Availability Statement: Not applicable.

Conflicts of Interest: The authors declare no conflict of interest.

\section{References}

1. Howe, L.R.; Subbaramaiah, K.; Hudis, C.A.; Dannenberg, A.J. Molecular pathways: Adipose inflammation as a mediator of obesity-associated cancer. Clin. Cancer Res. 2013, 19, 6074-6083. [CrossRef]

2. Baumgarten, S.C.; Frasor, J. Minireview: Inflammation: An instigator of more aggressive estrogen receptor (ER) positive breast cancers. Mol. Endocrinol. 2012, 26, 360-371. [CrossRef] [PubMed]

3. Hussein, M.R.; Hassan, H.I. Analysis of the mononuclear inflammatory cell infiltrate in the normal breast, benign proliferative breast disease, in situ and infiltrating ductal breast carcinomas: Preliminary observations. J. Clin. Pathol. 2006, 59, 972-977. [CrossRef] [PubMed]

4. Pollard, J.W. Macrophages define the invasive microenvironment in breast cancer. J. Leukoc. Biol. 2008, 84, 623-630. [CrossRef]

5. McDermott, R.S.; Beuvon, F.; Pauly, M.; Pallud, C.; Vincent-Salomon, A.; Mosseri, V.; Pouillart, P.; Scholl, S.M. Tumor antigens and antigen-presenting capacity in breast cancer. Pathobiology 2002, 70, 324-332. [CrossRef] [PubMed]

6. Greenberg, A.S.; Obin, M.S. Obesity and the role of adipose tissue in inflammation and metabolism. Am. J. Clin. Nutr. 2006, 83, 461S-465S. [CrossRef]

7. Weylandt, K.H.; Chiu, C.Y.; Gomolka, B.; Waechter, S.F.; Wiedenmann, B. Omega-3 fatty acids and their lipid mediators: Towards an understanding of resolvin and protectin formation. Prostaglandins Other Lipid Mediat. 2012, 97, 73-82. [CrossRef]

8. Turk, H.F.; Chapkin, R.S. Membrane lipid raft organization is uniquely modified by n-3 polyunsaturated fatty acids. Prostaglandins. Leukot. Essent. Fat. Acids 2013, 88, 43-47. [CrossRef] [PubMed]

9. Beloribi-Djefaflia, S.; Vasseur, S.; Guillaumond, F. Lipid metabolic reprogramming in cancer cells. Oncogenesis 2016, 5, e189. [CrossRef] 
10. Calder, P.C. n-3 fatty acids, inflammation and immunity: New mechanisms to explain old actions. Proc. Nutr. Soc. 2013, 72, 326-336. [CrossRef] [PubMed]

11. Ravacci, G.R.; Brentani, M.M.; Tortelli, T.; Torrinhas, R.S.M.; Saldanha, T.; Torres, E.A.F.; Waitzberg, D.L. Lipid raft disruption by docosahexaenoic acid induces apoptosis in transformed human mammary luminal epithelial cells harboring HER-2 overexpression. J. Nutr. Biochem. 2013, 24, 505-515. [CrossRef] [PubMed]

12. Manral, C.; Roy, S.; Singh, M.; Gautam, S.; Yadav, R.K.; Rawat, J.K.; Devi, U.; Ansari, M.N.; Saeedan, A.S.; Kaithwas, G. Effect of $\beta$-sitosterol against methyl nitrosourea-induced mammary gland carcinoma in albino rats. BMC Complementary Altern. Med. 2016, 16, 1-10. [CrossRef]

13. Rani, A.; Roy, S.; Singh, M.; Devi, U.; Yadav, R.K.; Gautam, S.; Rawat, J.K.; Ansari, M.N.; Saeedan, A.S.; Prakash, A.; et al. $\alpha$-Chymotrypsin regulates free fatty acids and UCHL-1 to ameliorate N-methyl nitrosourea induced mammary gland carcinoma in albino wistar rats. Inflammopharmacology 2016, 24, 277-286. [CrossRef] [PubMed]

14. Lee, E.J.; Yun, U.J.; Koo, K.H.; Sung, J.Y.; Shim, J.; Ye, S.K.; Hong, K.M.; Kim, Y.N. Down-regulation of lipid raft-associated onco-proteins via cholesterol-dependent lipid raft internalization in docosahexaenoic acid-induced apoptosis. Biochim. Et Biophys. Acta (BBA)-Mol. Cell Biol. Lipids 2014, 1841, 190-203. [CrossRef]

15. Yadav, S.; Tiwari, V.; Singh, M.; Yadav, R.K.; Roy, S.; Devi, U.; Gautam, S.; Rawat, J.K.; Ansari, M.N.; Saeedan, A.S.; et al. Comparative efficacy of alpha-linolenic acid and gamma-linolenic acid to attenuate valproic acid-induced autism-like features. $J$. Physiol. Biochem. 2017, 73, 187-198. [CrossRef]

16. Rogers, K.R.; Kikawa, K.D.; Mouradian, M.; Hernandez, K.; McKinnon, K.M.; Ahwah, S.M.; Pardini, R.S. Docosahexaenoic acid alters epidermal growth factor receptor-related signaling by disrupting its lipid raft association. Carcinogenesis 2010, 31, 1523-1530. [CrossRef]

17. Calder, P.C. Fatty acids and inflammation: The cutting edge between food and pharma. Eur. J. Pharmacol. 2011, 668, S50-S58. [CrossRef]

18. Wen, Z.H.; Su, Y.C.; Lai, P.L.; Zhang, Y.; Xu, Y.F.; Zhao, A.; Yao, G.Y.; Jia, C.H.; Lin, J.; Xu, S.; et al. Critical role of arachidonic acid-activated mTOR signaling in breast carcinogenesis and angiogenesis. Oncogene 2013, 32, 160-170. [CrossRef] [PubMed]

19. Yates, C.M.; Calder, P.C.; Rainger, G.E. Pharmacology and therapeutics of omega-3 polyunsaturated fatty acids in chronic inflammatory disease. Pharmacol. Ther. 2014, 141, 272-282. [CrossRef]

20. Simopoulos, A.P. Evolutionary aspects of diet, the omega-6/omega-3 ratio and genetic variation: Nutritional implications for chronic diseases. Biomed. Pharmacother. 2006, 60, 502-507. [CrossRef] [PubMed]

21. Friborg, J.T.; Melbye, M. Cancer patterns in Inuit populations. Lancet Oncol. 2008, 9, 892-900. [CrossRef]

22. Abel, S.; Riedel, S.; Gelderblom, W.C. Dietary PUFA and cancer. Proc. Nutr. Soc. 2014, 73, 361-367. [CrossRef]

23. Abramczyk, H.; Surmacki, J.; Kopeć, M.; Olejnik, A.K.; Lubecka-Pietruszewska, K.; Fabianowska-Majewska, K. The role of lipid droplets and adipocytes in cancer. Raman imaging of cell cultures: MCF10A, MCF7, and MDA-MB-231 compared to adipocytes in cancerous human breast tissue. Analyst 2015, 140, 2224-2235. [CrossRef] [PubMed]

24. Accioly, M.T.; Pacheco, P.; Maya-Monteiro, C.M.; Carrossini, N.; Robbs, B.K.; Oliveira, S.S.; Kaufmann, C.; Morgado-Diaz, J.A.; Bozza, P.T.; Viola, J.P. Lipid bodies are reservoirs of cyclooxygenase-2 and sites of prostaglandin-E2 synthesis in colon cancer cells. Cancer Res. 2008, 168, 1732-1740. [CrossRef]

25. Adachi, S.; Nagao, T.; Ingolfsson, H.I.; Maxfield, F.R.; Andersen, O.S.; Kopelovich, L.; Weinstein, I.B. The inhibitory effect of (-)-epigallocatechin gallate on activation of the epidermal growth factor receptor is associated with altered lipid order in HT29 colon cancer cells. Cancer Res. 2007, 67, 6493-6501. [CrossRef]

26. Agnihotri, N.; Sharma, G.; Rani, I.; Bhatnagar, A. Fish oil prevents colon cancer by modulation of structure and function of mitochondria. Biomed. Pharmacother. 2016, 82, 90-97. [CrossRef] [PubMed]

27. Altenburg, J.D.; Bieberich, A.A.; Terry, C.; Harvey, K.A.; VanHorn, J.F.; Xu, Z.; Davisson, V.J.; Siddiqui, R.A. A synergistic antiproliferation effect of curcumin and docosahexaenoic acid in SK-BR-3 breast cancer cells: Unique signaling not explained by the effects of either compound alone. BMC Cancer 2011, 11, 1-6. [CrossRef]

28. Ariotti, N.; Fernández-Rojo, M.A.; Zhou, Y.; Hill, M.M.; Rodkey, T.L.; Inder, K.L.; Tanner, L.B.; Wenk, M.R.; Hancock, J.F.; Parton, R.G. Caveolae regulate the nanoscale organization of the plasma membrane to remotely control Ras signaling. J. Cell Biol. 2014, 204, 777-792. [CrossRef]

29. Arora, A.; Singh, S.; Bhatt, A.N.; Pandey, S.; Sandhir, R.; Dwarakanath, B.S. Interplay between metabolism and oncogenic process: Role of microRNAs. Transl. Oncogenom. 2015, 7, 11.

30. Fuentes, N.R.; Kim, E.; Fan, Y.Y.; Chapkin, R.S. Omega-3 fatty acids, membrane remodeling and cancer prevention. Mol. Asp. Med. 2018, 64, 79-91. [CrossRef]

31. Baenke, F.; Peck, B.; Miess, H.; Schulze, A. Hooked on fat: The role of lipid synthesis in cancer metabolism and tumour development. Dis. Models Mech. 2013, 6, 1353-1363. [CrossRef] [PubMed]

32. Bancroft, L.K.; Lupton, J.R.; Davidson, L.A.; Taddeo, S.S.; Murphy, M.E.; Carroll, R.J.; Chapkin, R.S. Dietary fish oil reduces oxidative DNA damage in rat colonocytes. Free Radic. Biol. Med. 2003, 135, 149-159. [CrossRef]

33. Barker, N.; Van Es, J.H.; Kuipers, J.; Kujala, P.; Van Den Born, M.; Cozijnsen, M.; Haegebarth, A.; Korving, J.; Begthel, H.; Peters, P.J.; et al. Identification of stem cells in small intestine and colon by marker gene Lgr5. Nature 2007, 449, 1003-1007. [CrossRef] [PubMed] 
34. Barker, N.; Ridgway, R.A.; Van Es, J.H.; Van De Wetering, M.; Begthel, H.; Van Den Born, M.; Danenberg, E.; Clarke, A.R.; Sansom, O.J.; Clevers, H. Crypt stem cells as the cells-of-origin of intestinal cancer. Nature 2009, 457, 608-611. [CrossRef]

35. Barman, S.; Nayak, D.P. Lipid raft disruption by cholesterol depletion enhances influenza A virus budding from MDCK cells. J. Virol. 2007, 181, 12169-12178. [CrossRef] [PubMed]

36. Alagumuthu, M.; Dahiya, D.; Nigam, P.S. Phospholipid—the dynamic structure between living and non-living world; a much obligatory supramolecule for present and future. AIMS Mol. Sci. 2019, 26, 1-9.

37. Casares, D.; Escribá, P.V.; Rosselló, C.A. Membrane Lipid Composition: Effect on Membrane and Organelle Structure, Function and Compartmentalization and Therapeutic Avenues. Int. J. Mol. Sci. 2019, 20, 2167. [CrossRef]

38. Barrera, N.P.; Zhou, M.; Robinson, C.V. The role of lipids in defining membrane protein interactions: Insights from mass spectrometry. Trends Cell Biol. 2013, 23, 1-8. [CrossRef]

39. Bayram, I.; Erbey, F.; Celik, N.; Nelson, J.L.; Tanyeli, A. The use of a protein and energy dense eicosapentaenoic acid containing supplement for malignancy-related weight loss in children. Pediatric Blood Cancer 2009, 52, 571-574. [CrossRef]

40. Bene, L.; Bodnár, A.; Damjanovich, S.; Vámosi, G.; Bacsó, Z.; Aradi, J.; Berta, A.; Damjanovich, J. Membrane topography of HLA I, HLA II, and ICAM-1 is affected by IFN- $\gamma$ in lipid rafts of uveal melanomas. Biochem. Biophys. Res. Commun. 2004, 1322, 678-683. [CrossRef]

41. Beyaz, S.; Mana, M.D.; Roper, J.; Kedrin, D.; Saadatpour, A.; Hong, S.J.; Bauer-Rowe, K.E.; Xifaras, M.E.; Akkad, A.; Arias, E.; et al. High-fat diet enhances stemness and tumorigenicity of intestinal progenitors. Nature 2016, 531, 53-58. [CrossRef]

42. Bloch, K.E. Sterol, structure and membrane function. Crit. Rev. Biochem. 1983, 14, 47-92. [CrossRef]

43. Bohdanowicz, M.; Grinstein, S. Role of phospholipids in endocytosis, phagocytosis, and macropinocytosis. Physiol. Rev. 2013, 93, 69-106. [CrossRef] [PubMed]

44. Bost, F.; Decoux-Poullot, A.G.; Tanti, J.F.; Clavel, S. Energy disruptors: Rising stars in anticancer therapy? Oncogenesis 2016, 5, e188. [CrossRef] [PubMed]

45. Boudreau, D.M.; Gardner, J.S.; Malone, K.E.; Heckbert, S.R.; Blough, D.K.; Daling, J.R. The association between 3-hydroxy3-methylglutaryl conenzyme A inhibitor use and breast carcinoma risk among postmenopausal women. Cancer 2004, 100, 2308-2316. [CrossRef]

46. Bougnoux, P.; Hajjaji, N.; Ferrasson, M.N.; Giraudeau, B.; Couet, C.; Le Floch, O. Improving outcome of chemotherapy of metastatic breast cancer by docosahexaenoic acid: A phase II trial. Br. J. Cancer 2009, 101, 1978-1985. [CrossRef] [PubMed]

47. Bozza, P.T.; Viola, J.P. Lipid droplets in inflammation and cancer. Prostaglandins Leukot. Essent. Fat. Acids (PLEFA) 2010, 82, 243-250. [CrossRef]

48. Broitman, S.A.; Cerda, S.; Wilkinson, J. Cholesterol metabolism and colon cancer. Prog. Food Nutr. Sci. 1993, 17, 1-40.

49. Browning, L.M.; Walker, C.G.; Mander, A.P.; West, A.L.; Madden, J.; Gambell, J.M.; Young, S.; Wang, L.; Jebb, S.A.; Calder, P.C. Incorporation of eicosapentaenoic and docosahexaenoic acids into lipid pools when given as supplements providing doses equivalent to typical intakes of oily fish. Am. J. Clin. Nutr. 2012, 96, 748-758. [CrossRef]

50. Calder, P.C. Marine omega-3 fatty acids and inflammatory processes: Effects, mechanisms and clinical relevance. Biochim. Et Biophys. Acta (BBA)-Mol. Cell Biol. Lipids 2015, 1851, 469-484. [CrossRef]

51. Calviello, G.; Di Nicuolo, F.; Serini, S.; Piccioni, E.; Boninsegna, A.; Maggiano, N.; Ranelletti, F.O.; Palozza, P. Docosahexaenoic acid enhances the susceptibility of human colorectal cancer cells to 5-fluorouracil. Cancer Chemother. Pharmacol. 2005, 55, 12-20. [CrossRef]

52. Cardwell, C.; Hicks, B.M.; Hughes, C.; Murray, L.J. Statin Use After Colorectal Cancer Diagnosis and Survival: A Population-Based Cohort Study. J. Clin. Oncol. 2014, 32, 3177-3183. [CrossRef]

53. Cauley, J.A.; Zmuda, J.M.; Lui, L.Y.; Hillier, T.A.; Ness, R.B.; Stone, K.L.; Cummings, S.R.; Bauer, D.C. Lipid-lowering drug use and breast cancer in older women: A prospective study. J. Women's Health 2003, 12, 749-756. [CrossRef] [PubMed]

54. Singh, M.; Devi, U.; Roy, S.; Gupta, P.S.; Saraf, S.A.; Kaithwas, G. Prolyl hydroxylase mediated inhibition of fatty acid synthase to combat tumor growth in mammary gland carcinoma. Breast Cancer 2016, 23, 820-829. [CrossRef]

55. Singh, M.; Devi, U.; Roy, S.; Gupta, P.S.; Kaithwas, G. Chemical activation of prolyl hydroxylase-2 by BBAP-1 down regulates hypoxia inducible factor- $1 \alpha$ and fatty acid synthase for mammary gland chemoprevention. RSC Adv. 2018, 8, 12848-12860. [CrossRef]

56. Devi, U.; Singh, M.; Roy, S.; Tripathi, A.C.; Gupta, P.S.; Saraf, S.K.; Ansari, N.; Saeedan, A.S.; Kaithwas, G. PHD-2 activation: A novel strategy to control HIF- $1 \alpha$ and mitochondrial stress to modulate mammary gland pathophysiology in ER+ subtype. Naunyn-Schmiedeberg's Arch. Pharmacol. 2019, 392, 1239-1256. [CrossRef]

57. Cerchietti, L.C.; Navigante, A.H.; Castro, M.A. Effects of eicosapentaenoic and docosahexaenoic n-3 fatty acids from fish oil and preferential Cox-2 inhibition on systemic syndromes in patients with advanced lung cancer. Nutr. Cancer 2007, 159, 14-20. [CrossRef] [PubMed]

58. Roy, S.; Singh, M.; Rawat, A.; Devi, U.; Gautam, S.; Yadav, R.K.; Rawat, J.K.; Ansari, M.N.; Saeedan, A.S.; Kumar, D.; et al. GLA supplementation regulates PHD2 mediated hypoxia and mitochondrial apoptosis in DMBA induced mammary gland carcinoma. Int. J. Biochem. Cell Biol. 2018, 96, 51-62. [CrossRef] [PubMed]

59. Chandra, D.; Tang, D.G. Detection of apoptosis in cell-free systems. In Apoptosis; Humana Press: Totowa, NJ, USA, 2009; pp. 65-75. 
60. Chapkin, R.S. Fatty acids in foods and their health implications. In Reappraisal of the Essential Fatty Acids, 2nd ed.; Marcel Dekker Inc.: New York, NY, USA, 2000; pp. 557-568.

61. Chapkin, R.S.; Akoh, C.C.; Miller, C.C. Influence of dietary n-3 fatty acids on macrophage glycerophospholipid molecular species and peptidoleukotriene synthesis. J. Lipid Res. 1991, 32, 1205-1213. [CrossRef]

62. Chapkin, R.S.; Hong, M.Y.; Fan, Y.Y.; Davidson, L.A.; Sanders, L.M.; Henderson, C.E.; Barhoumi, R.; Burghardt, R.C.; Turner, N.D.; Lupton, J.R. Dietary n- 3 PUFA alter colonocyte mitochondrial membrane composition and function. Lipids 2002, 37, 193-199. [CrossRef]

63. Chapkin, R.S.; Wang, N.; Fan, Y.Y.; Lupton, J.R.; Prior, I.A. Docosahexaenoic acid alters the size and distribution of cell surface microdomains. Biochim. Et Biophys. Acta (BBA)-Biomembr. 2008, 1778, 466-471. [CrossRef] [PubMed]

64. Chapkin, R.S.; DeClercq, V.; Kim, E.; Fuentes, N.R.; Fan, Y.Y. Mechanisms by which pleiotropic amphiphilic n-3 PUFA reduce colon cancer risk. Curr. Colorectal Cancer Rep. 2014, 10, 442-452. [CrossRef]

65. Cho, Y.; Kim, H.; Turner, N.D.; Mann, J.C.; Wei, J.; Taddeo, S.S.; Davidson, L.A.; Wang, N.; Vannucci, M.; Carroll, R.J.; et al. A chemoprotective fish oil-and pectin-containing diet temporally alters gene expression profiles in exfoliated rat colonocytes throughout oncogenesis. J. Nutr. 2011, 141, 1029-1035. [CrossRef] [PubMed]

66. Cho, Y.; Turner, N.D.; Davidson, L.A.; Chapkin, R.S.; Carroll, R.J.; Lupton, J.R. A chemoprotective fish oil/pectin diet enhances apoptosis via Bcl-2 promoter methylation in rat azoxymethane-induced carcinomas. Exp. Biol. Med. 2012, 237, 1387-1393. [CrossRef] [PubMed]

67. Cho, Y.; Turner, N.D.; Davidson, L.A.; Chapkin, R.S.; Carroll, R.J.; Lupton, J.R. Colon cancer cell apoptosis is induced by combined exposure to the n-3 fatty acid docosahexaenoic acid and butyrate through promoter methylation. Exp. Biol. Med. 2014, 239, 302-310. [CrossRef] [PubMed]

68. Roy, S.; Rawat, A.K.; Sammi, S.R.; Devi, U.; Singh, M.; Gautam, S.; Yadav, R.K.; Rawat, J.K.; Singh, L.; Ansari, M.N.; et al. Alpha-linolenic acid stabilizes HIF-1 $\alpha$ and downregulates FASN to promote mitochondrial apoptosis for mammary gland chemoprevention. Oncotarget 2017, 18, 70049. [CrossRef]

69. Yadav, R.K.; Singh, M.; Roy, S.; Ansari, M.N.; Saeedan, A.S.; Kaithwas, G. Modulation of oxidative stress response by flaxseed oil: Role of lipid peroxidation and underlying mechanisms. Prostaglandins Lipid Mediat. 2018, 135, 21-26. [CrossRef]

70. Erlejman, A.G.; Verstraeten, S.V.; Fraga, C.G.; Oteiza, P.I. The interaction of flavonoids with membranes: Potential determinant of flavonoid antioxidant effects. Free Radic. Res. 2004, 38, 1311-1320. [CrossRef]

71. Fabian, C.J.; Kimler, B.F.; Phillips, T.A.; Nydegger, J.L.; Kreutzjans, A.L.; Carlson, S.E.; Hidaka, B.; Metheny, T.; Zalles, C.M.; Mills, G.B.; et al. Modulation of Breast Cancer Risk Biomarkers by High-Dose Omega-3 Fatty Acids: Phase II Pilot Study in Postmenopausal Women. Cancer Prev. Res. 2015, 8, 922-931. [CrossRef]

72. Fahrmann, J.F.; Hardman, W.E. Omega 3 fatty acids increase the chemo-sensitivity of B-CLL-derived cell lines EHEB and MEC-2 and of B-PLL-derived cell line JVM-2 to anti-cancer drugs doxorubicin, vincristine and fludarabine. Lipids Health Dis. 2013, 12, 1-3. [CrossRef] [PubMed]

73. Gautam, S.; Roy, S.; Ansari, M.N.; Saeedan, A.S.; Saraf, S.A.; Kaithwas, G. DuCLOX-2/5 inhibition: A promising target for cancer chemoprevention. Breast Cancer 2016, 24, 180-190. [CrossRef] [PubMed]

74. Fan, Y.Y.; Ran, Q.; Toyokuni, S.; Okazaki, Y.; Callaway, E.S.; Lupton, J.R.; Chapkin, R.S. Dietary fish oil promotes colonic apoptosis and mitochondrial proton leak in oxidatively stressed mice. Cancer Prev. Res. 2011, 4, 1267-1274. [CrossRef] [PubMed]

75. Fan, Y.Y.; Zhan, Y.; Aukema, H.M.; Davidson, L.A.; Zhou, L.; Callaway, E.; Tian, Y.; Weeks, B.R.; Lupton, J.R.; Toyokuni, S.; et al. Proapoptotic effects of dietary (n-3) fatty acids are enhanced in colonocytes of manganese-dependent superoxide dismutase knockout mice. J. Nutr. 2009, 139, 1328-1332. [CrossRef] [PubMed]

76. Yadav, R.K.; Singh, M.; Roy, S.; Gautam, S.; Rawat, J.K.; Singh, L.; Ansari, M.N.; Saeedan, A.S.; Kaithwas, G. Short communication: Evaluation of $\alpha$-linolenic acid-based intramammary nanosuspension for treatment of subclinical mastitis. J. Dairy Sci. 2020, 103, 2701-2706. [CrossRef]

77. Fan, Y.Y.; Vaz, F.M.; Chapkin, R.S. Dietary fat and fiber interactively modulate apoptosis and mitochondrial bioenergetic profiles in mouse colon in a site-specific manner. Eur. J. Cancer Prev. Off. J. Eur. Cancer Prev. Organ. (ECP) 2017, 26, 301. [CrossRef]

78. Fearon, K.C.; Barber, M.D.; Moses, A.G.; Ahmedzai, S.H.; Taylor, G.S.; Tisdale, M.J.; Murray, G.D. Double-blind, placebocontrolled, randomized study of eicosapentaenoic acid diester in patients with cancer cachexia. J. Clin. Oncol. 2006, 224, 3401-3407. [CrossRef]

79. Fedida-Metula, S.; Feldman, B.; Koshelev, V.; Levin-Gromiko, U.; Voronov, E.; Fishman, D. Lipid rafts couple store-operated Ca 2+ entry to constitutive activation of PKB/Akt in a Ca 2+ /calmodulin-, Src- and PP2A-mediated pathway and promote melanoma tumor growth. Carcinogenesis 2012, 33, 740-750. [CrossRef]

80. Feng, Y.; Schouteden, S.; Geenens, R.; Van Duppen, V.; Herijgers, P.; Holvoet, P.; Van Veldhoven, P.P.; Verfaillie, C.M. Hematopoietic stem/progenitor cell proliferation and differentiation is differentially regulated by high-density and low-density lipoproteins in mice. PLoS ONE 2012, 7, e47286. [CrossRef]

81. Roy, S.; Singh, M.; Sammi, S.R.; Pandey, R.; Kaithwas, G. ALA-mediated biphasic downregulation of $\alpha-7 n A c h R / H I F-1 \alpha$ along with mitochondrial stress modulation strategy in mammary gland chemoprevention. J. Cell. Physiol. 2019, 234, 4015-4029. [CrossRef] [PubMed] 
82. Finocchiaro, C.; Segre, O.; Fadda, M.; Monge, T.; Scigliano, M.; Schena, M.; Tinivella, M.; Tiozzo, E.; Catalano, M.G.; Pugliese, M.; et al. Effect of n-3 fatty acids on patients with advanced lung cancer: A double-blind, placebo-controlled study. Br. J. Nutr. 2012, 108, 327-333. [CrossRef]

83. Forones, N.M.; Falcao, J.B.; Mattos, D.; Barone, B. Cholesterolemia in colorectal cancer. Hepato-Gastroenterol. 1998, 45, 1531-1534. [PubMed]

84. Frisz, J.F.; Lou, K.; Klitzing, H.A.; Hanafin, W.P.; Lizunov, V.; Wilson, R.L.; Carpenter, K.J.; Kim, R.; Hutcheon, I.D.; Zimmerberg, J.; et al. Direct chemical evidence for sphingolipid domains in the plasma membranes of fibroblasts. Proc. Natl. Acad. Sci. USA 2013, 1110, E613-E622. [CrossRef] [PubMed]

85. Fuentes, N.R.; Salinas, M.L.; Kim, E.; Chapkin, R.S. Emerging role of chemoprotective agents in the dynamic shaping of plasma membrane organization. Biochim. Et Biophys. Acta (BBA)-Biomembr. 2017, 1859, 1668-1678. [CrossRef]

86. Roy, S.; Singh, M.; Rawat, A.; Kumar, D.; Kaithwas, G. Mitochondrial apoptosis and curtailment of hypoxia-inducible factor$1 \alpha /$ fatty acid synthase: A dual edge perspective of gamma linolenic acid in ER+ mammary gland cancer. Cell Biochem. Funct. 2020, 38, 591-603. [CrossRef] [PubMed]

87. Fulda, S.; Galluzzi, L.; Kroemer, G. Targeting mitochondria for cancer therapy. Nat. Rev. Drug Discov. 2010, 9, 447-464. [CrossRef]

88. Gabitova, L.; Restifo, D.; Gorin, A.; Manocha, K.; Handorf, E.; Yang, D.H.; Cai, K.Q.; Klein-Szanto, A.J.; Cunningham, D.; Kratz, L.E.; et al. Endogenous sterol metabolites regulate growth of EGFR/KRAS-dependent tumors via LXR. Cell Rep. 2015, 212, 1927-1938. [CrossRef]

89. Garcia-Parajo, M.F.; Cambi, A.; Torreno-Pina, J.A.; Thompson, N.; Jacobson, K. Nanoclustering as a dominant feature of plasma membrane organization. J. Cell Sci. 2014, 127, 4995-5005. [CrossRef]

90. Garwood, E.R.; Kumar, A.S.; Baehner, F.L.; Moore, D.H.; Au, A.; Hylton, N.; Flowers, C.I.; Garber, J.; Lesnikoski, B.A.; Hwang, E.S.; et al. Fluvastatin reduces proliferation and increases apoptosis in women with high grade breast cancer. Breast Cancer Res. Treat. 2010, 119, 137-144. [CrossRef]

91. Adachi, K.; Toyota, M.; Sasaki, Y.; Yamashita, T.; Ishida, S.; Ohe-Toyota, M.; Maruyama, R.; Hinoda, Y.; Saito, T.; Imai, K.; et al. Identification of SCN3B as a novel p53-inducible proapoptotic gene. Oncogene 2004, 23, 7791-7798. [CrossRef]

92. Agwa, A.J.; Peigneur, S.; Chow, C.Y.; Lawrence, N.; Craik, D.J.; Tytgat, J.; King, G.F.; Henriques, S.T.; Schroeder, C.I. Gating modifier toxins isolated from spider venom: Modulation of voltage-gated sodium channels and the role of lipid membranes. J. Biol. Chem. 2018, 293, 9041-9052. [CrossRef]

93. Amara, S.; Ivy, M.T.; Myles, E.L.; Tiriveedhi, V. Sodium channel $\gamma \mathrm{ENaC}$ mediates IL-17 synergized high salt induced inflammatory stress in breast cancer cells. Cell. Immunol. 2016, 302, 1-10. [CrossRef] [PubMed]

94. Arnold, M.; Sierra, M.S.; Laversanne, M.; Soerjomataram, I.; Jemal, A.; Bray, F. Global patterns and trends in colorectal cancer incidence and mortality. Gut 2017, 66, 683-691. [CrossRef] [PubMed]

95. Baptista-Hon, D.; Robertson, F.; Robertson, G.; Owen, S.; Rogers, G.; Lydon, E.; Lee, N.; Hales, T. Potent inhibition by ropivacaine of metastatic colon cancer SW620 cell invasion and Na V 1.5 channel function. Br. J. Anaesth. 2014, 113, i39-i48. [CrossRef]

96. Batcioglu, K.; Uyumlu, A.B.; Satilmis, B.; Yildirim, B.; Yucel, N.; Demirtas, H.; Onkal, R.; Guzel, R.M.; Djamgoz, M.B. Oxidative Stress in the in vivo DMBA Rat Model of Breast Cancer: Suppression by a Voltage-gated Sodium Channel Inhibitor (RS 100642). Basic Clin. Pharmacol. Toxicol. 2012, 111, 137-141. [CrossRef]

97. 97. Bergareche, A.; Bednarz, M.; Sánchez, E.; Krebs, C.E.; Ruiz-Martinez, J.; De La Riva, P.; Makarov, V.; Gorostidi, A.; Jurkat-Rott, K.; Marti-Masso, J.F.; et al. SCN4A pore mutation pathogenetically contributes to autosomal dominant essential tremor and may increase susceptibility to epilepsy. Hum. Mol. Genet. 2015, 24, 7111-7120. [CrossRef]

98. Biswas, A.K.; Acharyya, S. Understanding cachexia in the context of metastatic progression. Nat. Rev. Cancer 2020, 20, 274-284. [CrossRef] [PubMed]

99. Mollinedo, F.; Gajate, C.; Martín-Santamaría, S.; Gago, F. ET-18-OCH3 (edelfosine): A selective antitumour lipid targeting apoptosis through intracellular activation of Fas/CD95 death receptor. Curr. Med. Chem. 2004, 11, 3163-3184. [CrossRef]

100. Delmas, D.; Aires, V.; Colin, D.J.; Limagne, E.; Scagliarini, A.; Cotte, A.K.; Ghiringhelli, F. Importance of lipid microdomains, rafts, in absorption, delivery, and biological effects of resveratrol. Ann. N. Y. Acad. Sci. 2013, 1290, 90-97. [CrossRef]

101. Veldman, R.J.; Zerp, S.; Van Blitterswijk, W.J.; Verheij, M. N-hexanoyl-sphingomyelin potentiates in vitro doxorubicin cytotoxicity by enhancing its cellular influx. Br. J. Cancer 2004, 90, 917-925. [CrossRef]

102. Van Hell, A.J.; Melo, M.N.; Van Blitterswijk, W.J.; Gueth, D.M.; Braumuller, T.M.; Pedrosa, L.R.; Song, J.Y.; Marrink, S.J.; Koning, G.A.; Jonkers, J.; et al. Defined lipid analogues induce transient channels to facilitate drug-membrane traversal and circumvent cancer therapy resistance. Sci. Rep. 2013, 3, 1-8. [CrossRef] [PubMed]

103. Novotný, J.; Janůsová, B.; Novotný, M.; Hrabálek, A.; Vavrova, K. Short-Chain Ceramides Decrease Skin Barrier Properties. Ski. Pharmacol. Physiol. 2009, 22, 22-30. [CrossRef]

104. Grösch, S.; Schiffmann, S.; Geisslinger, G. Chain length-specific properties of ceramides. Prog. Lipid Res. 2012, 51, 50-62. [CrossRef]

105. Chiantia, S.; Kahya, N.; Schwille, P. Raft domain reorganization driven by short-and long-chain ceramide: A combined AFM and FCS study. Langmuir 2007, 23, 7659-7665. [CrossRef] [PubMed]

106. van Lummel, M.; van Blitterswijk, W.J.; Vink, S.R.; Veldman, R.J.; van der Valk, M.A.; Schipper, D.; Dicheva, B.M.; Eggermont, A.M.; Hagen, T.L.; Verheij, M.; et al. Enriching lipid nanovesicles with short-chain glucosylceramide improves doxorubicin delivery and efficacy in solid tumors. FASEB J. 2011, 25, 280-289. [CrossRef] [PubMed] 